\title{
Studies on Pollution Hazards of Shallow Hand-Dug Wells in Erena and Environs, North-Central Nigeria
}

\author{
Amadi A. N. ${ }^{1}$, Dan-Hassan M. A. ${ }^{2}$, Okoye N. O. ${ }^{1}$, Ejiofor I. C. ${ }^{1} \&$ Aminu Tukur ${ }^{3}$ \\ ${ }^{1}$ Department of Geology, Federal University of Technology, Minna, Nigeria \\ ${ }^{2}$ Rural Water Supply and Sanitation Department, FCT Water Board, Garki, Abuja, Nigeria \\ ${ }^{3}$ Katsina State Rural Water Supply and Sanitation Agency, Nigeria \\ Correspondence: Amadi A. N., Department of Geology, Federal University of Technology, Minna, Nigeria. \\ E-mail: geoama76@gmail.com
}

Received: December 30, 2012 Accepted: February 20, 2013 Online Published: February 25, 2013

doi:10.5539/enrr.v3n2p69

URL: http://dx.doi.org/10.5539/enrr.v3n2p69

\begin{abstract}
This present study evaluates the pollution status of shallow hand-dug wells in Erena community, Shiroro Local Government Area of Niger State, North-central Nigeria using pollution index. The application of pollution index on the hydrochemical data revealed that the groundwater from the shallow aquifers in Erena area had serious bacteriological pollution and moderately/slightly pollution coming from $\mathrm{pH}$, iron and bicarbonate, while the pollution status of the remaining parameters are within the acceptable limit for a potable water. The observed microbial pollution arising from the presence of total coliform and E. coli in the well water are due to migration of plume from un-lined pit-latrines/soakaway while the enrichment of the well water with low $\mathrm{pH}$, high iron and bicarbonate can be attributed to natural sources arising from bedrock dissolution. Results of well water samples collected far away from the pit-latrines/soakaway show no microbial contaminant. The dominant hydrochemical facies as revealed by Piper diagram are $\mathrm{Ca}-\mathrm{Mg} / \mathrm{CO}_{3}-\mathrm{HCO}_{3}$. Boiling of the water before drinking is recommended as most bacteria do not withstand very high temperature. Future hand-dug wells and boreholes in the area should be sited far away from the existing pit-latrines/soakaway and groundwater should be tapped from deeper aquifers. The use of sanitary VIP-latrines and well-lined soakaway system were proposed. Niger State Ministries of Environment and Water Resources should organize workshops and seminars in the area as means of creating the needed awareness on the benefits of good hygiene and clean environment to man.
\end{abstract}

Keywords: evaluation, pollution hazard, shallow aquifers, Erena, north-central Nigeria

\section{Introduction}

Inadequate supply of good potable pipe-borne water in most urban centers and its absent in rural communities are common phenomenon in most African countries. As a result, groundwater is the only source of potable water because the temperature its almost consistent and chemical quality demands little or no purification and treatment mechanism. Apart from grossly insufficient potable water supply experienced in state capitals in most developing countries, a combination of lack of good quality water and improper sanitation practices remains a common environmental problem in urban, semi-urban and rural areas. The rapid growth in population coupled with steady increase in water demand for agricultural and industrial uses in developing nations have imposed stress on groundwater resources both quantitatively and qualitatively. Increasing contamination of the surface water such as rivers, streams and ponds in developing countries as a result of increase in population, urbanization and industrialization has resulted to groundwater pollution especially those tapping water from shallow unconfined aquifers (Amadi, 2011). Groundwater is a valuable natural resource for various human activities (Prasad \& Kumari, 2008). Groundwater moves through pore-spaces within rocks and reacts with minerals that make up the rocks in the course of migration (Amadi et al., 2012b). These minerals may be soluble or insoluble and hence, an increases or decreases in groundwater composition may occur as it migrates. As groundwater moves, it is filtered naturally until equilibrium of the dissolved substances is achieved (Olorunfemi \& Fasuyi, 1993; Amadi et al., 2012a).

The amount and type of dissolved ions in groundwater is a composition of the local geology, geochemical characteristics, prevailing human activities and application (Ezeigbo, 1989). Groundwater is the most economic 
source of potable water for urban, semi-urban and rural areas in Nigeria because of its known advantages over surface water (Olasehinde \& Amadi, 2009). The deterioration of groundwater in terms of quality through anthropogenic interference as well as geogenic means is the main causes of water pollution in under- developed countries. Groundwater quality in any locality takes after the chemical composition of the aquifer through which it migrates in accordance with the hydrological cycle and flow direction (Offodile, 1983; Amadi et al., 2010).

The groundwater from the shallow hand-dug wells of perched aquifers system in Erena and environs was investigated in this study with the aim of ascertaining their suitability for drinking and other purposes. The poor on-site sanitation in the vicinity of some hand-dug well (Plates 1and 2) and possibility of contaminating groundwater from shallow aquifers necessitated the present study.

\section{Materials and Methods}

\subsection{Study Area Description}

Erena is one of the major towns that make up Shiroro Local Government Area of Niger State (Figure 1). The Shiroro Local Government Area is strategic because it hosts one of the biggest Nigerian hydroelectric dams. It is located on Longitude $6^{\circ} 40^{\prime} \mathrm{E}$ to $6^{\circ} 48^{\prime} \mathrm{E}$ and Latitude $10^{\circ} 02^{\prime} \mathrm{N}$ to $10^{\circ} 10^{\prime} \mathrm{N}$ approximately. The people of the study area engage in trading, farming and fishing as means of livelihood. The area is generally low lying with some conspicuous hills and the area is well drained by River Shiroro and its tributaries.

\subsection{Synopsis of the Geology of the Study Area}

The study area falls within the North-central portion of the Basement Complex rocks of Nigeria which is composed of three lithological units: migmatite-gneiss complex, low grade schist belts and the older granite (McCurry, 1983; Ajibade \& Wright, 1988; Olarewaju et al., 1996; Olasehinde, 1999). About 50\% of the entire landmass of Niger State is underlain by the hard-rocks belonging to the Basement Complex of Precambrian age while the remaining $50 \%$ is outcropped by the soft-rocks of Cretaceous age belonging to the Bida Basin sedimentary rock (Figure 2). Detailed geological mapping carried out in the area also reveaded that the area is underlain by granites, schist and gneiss with granites occupying greater portion of the area.

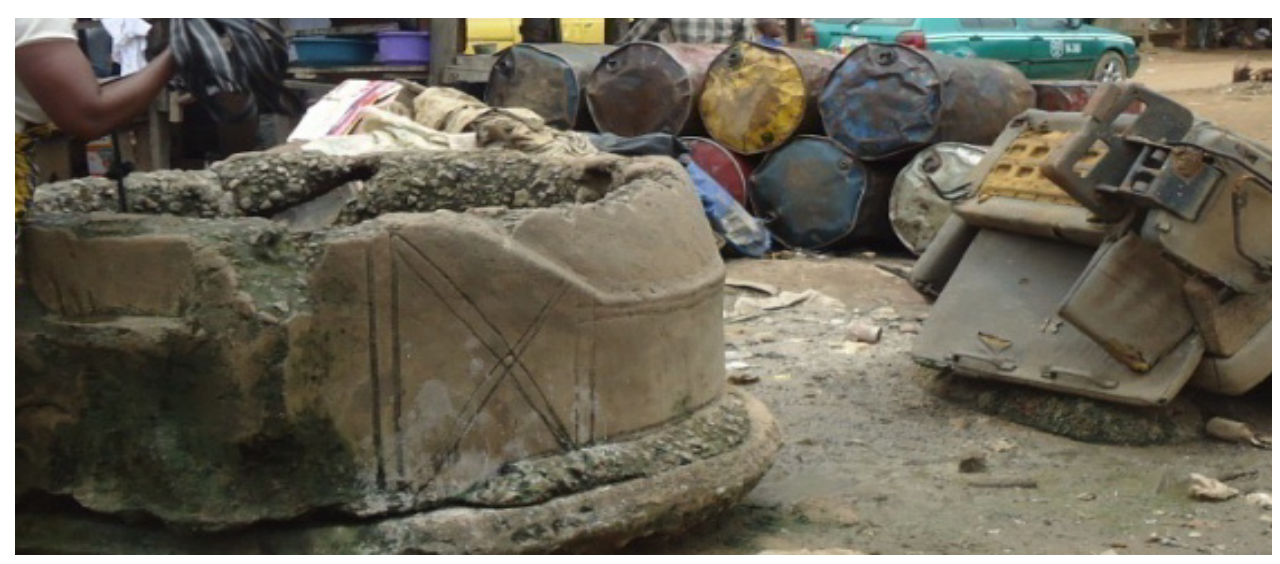

Plate 1. Poor on-site sanitation around a hand-dug well at Erena

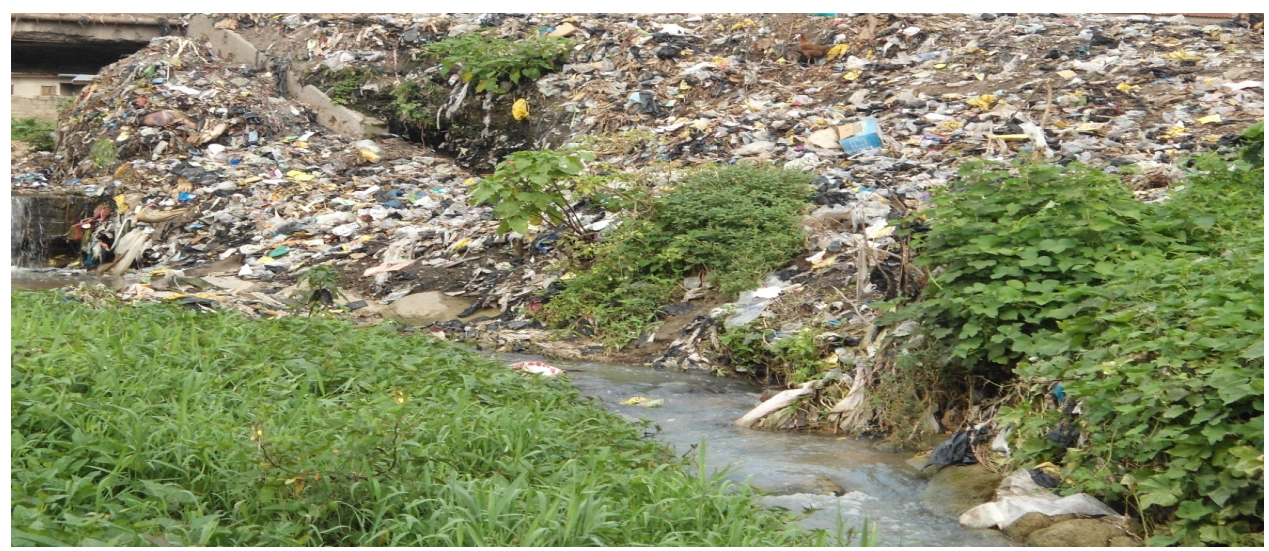

Plate 2. Dumpsite close to a hand-dug well in the area 


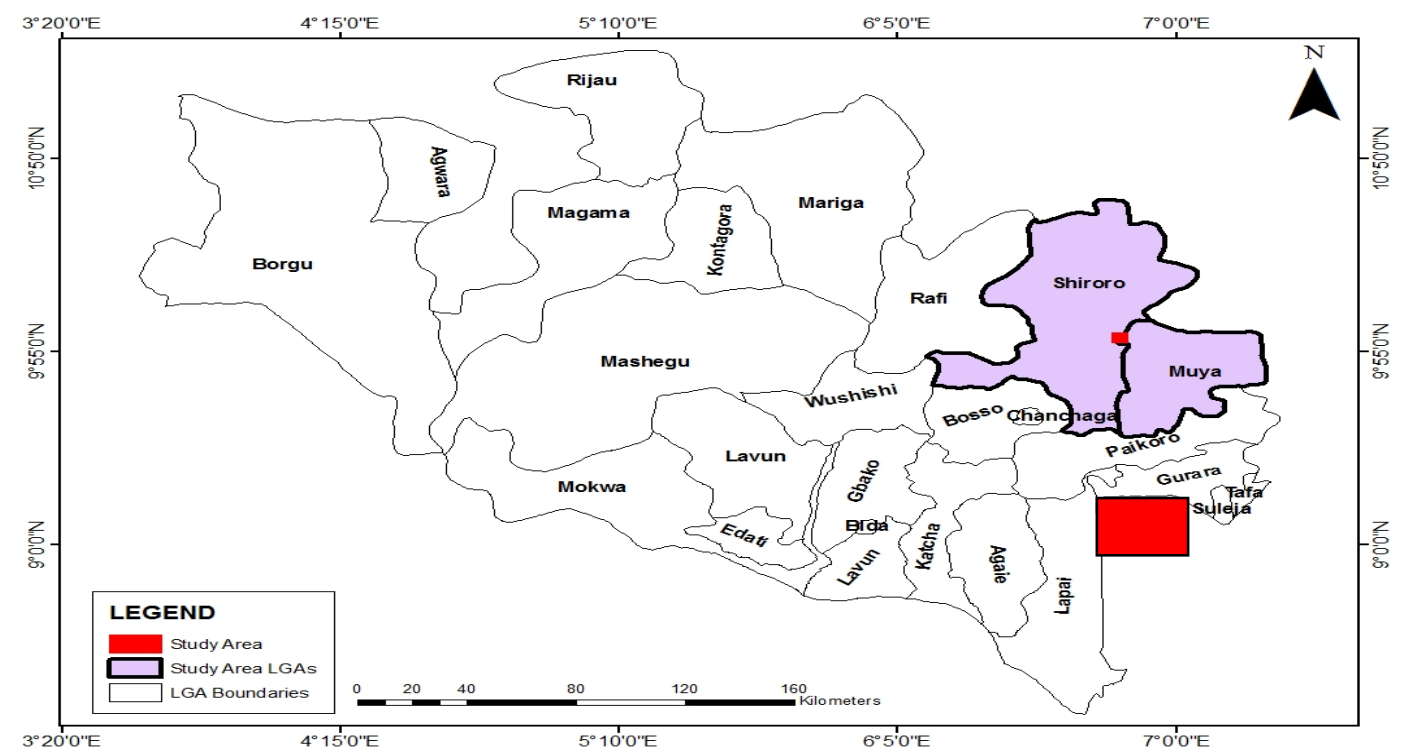

Figure 1. Niger State map indicating the area of study

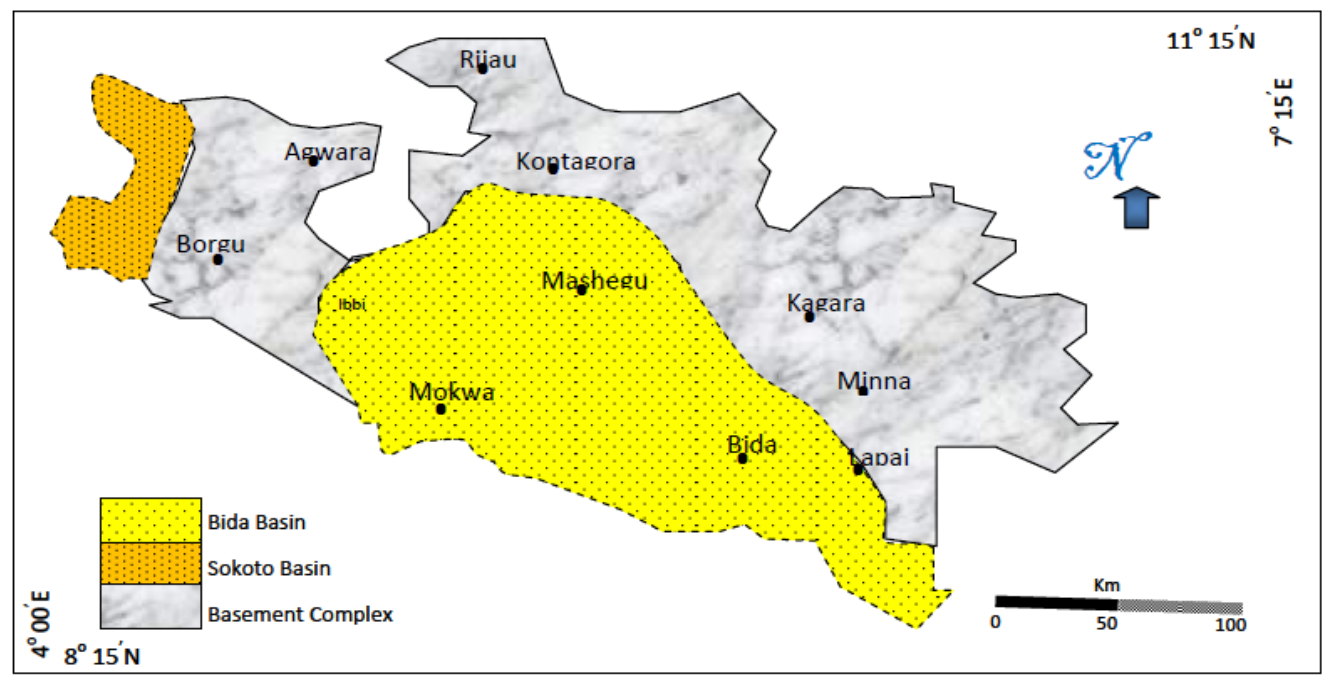

Figure 2. Geology map of Niger State showing the Basement and sedimentary rocks

\subsection{Sampling and Analytical Procedures}

A total of 42 water samples were taken from the shallow hand-dug wells in the area following standard sampling procedures. The sampling took place in the month of September and the samples were transported to the laboratory as soon as sample collection was concluded, for relevant physico-chemical and bacteriological analysis. The measurement of the following physical parameter: $\mathrm{pH}$, temperature, conductivity and turbidity were carried out in-situ (on site) using their appropriate instruments in line with the specified standards (APHA, 1998). Glass and plastic containers were used to collect the samples at each location. Two drops of concentrated $\mathrm{HNO}_{3}$ were added to the water samples in the plastic container (Schroll, 1976). The water samples in the plastic containers were used for the determination of major cations and heavy metals while the water samples in the glass container are for the determination of the anions.

The samples were analyzed for 21 parameters which include: total hardness (TH), chloride, potassium, sodium, calcium, magnesium, electrical conductivity (EC), total dissolved solids (TDS), dissolved oxygen (DO), temperature, turbidity, $\mathrm{pH}$, iron, copper, zinc, bicarbonate, nitrate, sulphate, chromium, E-coli and total coliform (TC). Sodium and potassium were analyzed by Flame Photometer (model CL-360, Elico, India) while calcium and magnesium were analyzed using AAS (model Analyst 300, Perkins-Elmer, USA). 
The heavy metals (iron, copper, zinc and chromium were determined with same AAS after sample digestion with nitric-perchloric acid mixture $(5: 1)$. TDS was determined gravimetrically while bicarbonate and TH were analyzed by acid-base titration method. Chloride, nitrate and sulphate were analyzed using modular Ion Chromatograph (Metrohm, Switzerland) having a Metrohm IC-709 programmable pump, Metrohm IC-733 separation centre, Metrohm IC-753 suppressor module and a Metrohm IC-732 conductivity detector. Dissolved oxygen was determined by chromate reflux method while the analyses of total coliform and E.coli were carried out using presumptive and differential counts respectively.

\subsection{Pollution Index}

Pollution is the introduction of contaminants into the natural environment that causes adverse change on the recepient. It is created mostly by human actions, but can also be natural in some cases. A groundwater pollutant is any substance that, when it reaches an aquifer, makes the water unclean or otherwise unsuitable for a particular purpose. Sometimes the substance is a manufactured chemical or microbial contamination. Groundwater contamination can also occur from naturally occurring mineral and metallic deposits in rock and soil which host the groundwater or in the course of its movement.

Pollution index (PI) is a method of rating that shows the composite influence of individual parameters on the overall quality of water (Amadi, 2011; Amadi et al., 2012b). The rating has values starting from zero to five or above (Table 2), reflecting the relative importance individual quality parameter and divided by the recommended standard ( $\mathrm{Si}$ ) for the maximum plus the minimum values and the summation divided by two as shown below. Water quality and its suitability for drinking purpose can be examined by mdetermining its quality index (Caerio et al., 2005; Prasad \& Kumari, 2008; Prasad \& Mondal, 2008; Amadi, 2012).

$$
P I=\sqrt{\frac{\left[\frac{C i}{S i}\right]_{\max }^{2}+\left[\frac{C i}{S i}\right]_{\text {min }}^{2}}{2}}
$$

Where:

PI: pollution index

$C i$ : mean concentration

Si: Nigerian Standard for Drinking Water Quality (NSDWQ, 2007)

\section{Results and Discussion}

A summary of the results of the water analysis is contained in Table 1. It can be observed from Table 1, that the concentration of majority of the physico-chemical parameters falls below the recommended limited for a safe drinking water by Nigerian Standard for Drinking Water Quality (NSDWQ, 2007) except for $\mathrm{pH}$, iron and bicarbonate. Their presence in the groundwater may be attributed to natural dissolution due to weathering phenomenon. However, the shallow aquifer from the hand-dug well has seriously bacteriological contamination (with total coliform), which could arise from groundwater in contact with human and animal faeces (Figures 3 and 4). It can also result from other means such as poor sanitary habit displayed by the host communities (Plates 1 and 2). Similarly, the concentration of the heavy metals (iron, zinc, copper and chromium) falls within the permissible limits of (NSDWQ, 2007). Iron in few locations has high concentration but this does not pose any health hazard, rather they water may appear coloured and tasty (WHO, 2006; Amadi et al., 2012b). High iron content in the water may be due to chemical weathering of the bedrock into lateritic soils and subsequent downward leaching into the shallow aquiferous zones in the area (Amadi et al., 2012a).

The concentrations of total hardness (TH) and total dissolved solid (TDS) are below the recommended maximum permissible limit of $150.00 \mathrm{mg} / \mathrm{l}$ and $500.00 \mathrm{mg} / 1$ respectively (NSDWQ, 2007). Calcium and magnesium ions in water may give rise to hardness and it does not pose any danger in respect to quality. The dissolutions of cations and anions in the host-rock by groundwater in the course of its movement accounts for the higher concentration of total dissolved solid (TDS) and electrical conductivity (EC) in groundwater. Water in its pure state does not conduct electricity, but does when ions are dissolved in it. The conductivity and turbidity of water may be due to the dissolved and or suspended solid carried by groundwater.

Temperature values and dissolved oxygen are within Nigerian Standard for Drinking Water Quality (NSDWQ, 2007) acceptable limit. The $\mathrm{pH}$ values indicate alkalinity, which may be attributed to bedrock weathering. The presence of E.coli and total coliform (TC) were detected in all the water samples suggest faecal contamination by human and animal faeces in groundwater system. Many households in the area lack standard toilets and soakaways, and the excreta are dumped on the ground and stream channel. During rainfall, it may get infiltrated 
in to soil and can later get into the perched aquifers. Furthermore, some hand-dug wells are located very close to pit-toilet/soakaway, thus the water may get contaminated in the course of its movement.

All the parameters analyzed were subjected to pollution indexing approach and the results were tabulated in Table 1. A closer look at the result revealed that all the parameters analyzed fall within classes 1 and 2 indicating no pollution and slightly polluted respectively except total coliform (TC) that falls in class 5 signifying seriously polluted (Table 2). This implies that the hand-dug wells in the study area have experienced varying degree of bacteriological contamination as a result of unhealthy sanitary habit exhibited by the people in the area. The tendency of human faeces migrating from un-lined pit-latrine/soakaway into the shallow, porous and permeable aquifer cannot be over-emphasized. Once the 15 meters minimum safe distance between a hand-dug well/boreholes and a soakaway/pit-latrine is compromised due to one reason or the other, faecal contamination is inevitable. This if not properly managed can result to some water borne diseases, that can affect the healthy living condition of the people in the especially women and children.

Table 1. Statistical summary of water samples from the area

\begin{tabular}{cccccc}
\hline Parameters (mg/l) & Minimum & Maximum & Mean & NSDWQ & Pollution Index \\
\hline TH & 43.00 & 203.00 & 107.50 & 500.00 & 0.29 \\
Chloride & 4.09 & 37.40 & 23.46 & 250.00 & 0.11 \\
Potassium & 1.20 & 24.80 & 13.40 & 150.00 & 0.12 \\
Sodium & 2.50 & 38.50 & 21.60 & 200.00 & 0.14 \\
Calcium & 12.83 & 59.30 & 35.77 & 200.00 & 0.22 \\
Magnesium & 1.22 & 20.98 & 7.77 & 200.00 & 0.07 \\
EC ( $\mu$ s/cm) & 126.00 & 600.00 & 304.50 & 1000.0 & 0.43 \\
TDS & 84.42 & 402.00 & 204.03 & 500.00 & 0.58 \\
DO & 5.71 & 6.71 & 6.33 & 10.00 & 0.62 \\
pH & 7.71 & 8.70 & 8.25 & 7.50 & 1.10 \\
Iron & 0.04 & 0.54 & 0.35 & 0.30 & 1.04 \\
Copper & 0.00 & 0.32 & 0.13 & 1.00 & 0.23 \\
Zinc & 0.00 & 0.12 & 0.05 & 3.00 & 0.03 \\
Bicarbonate & 100.00 & 190.00 & 136.00 & 100.00 & 1.52 \\
Nitrate & 9.00 & 43.00 & 20.90 & 50.00 & 0.62 \\
Sulphate & 8.00 & 44.00 & 23.80 & 250.00 & 0.13 \\
Chromium & 0.00 & 0.01 & 0.001 & 0.05 & 0.01 \\
E.coli (cfu/ml) & 0.00 & 1.00 & 0.20 & 0.00 & 0.00 \\
TC (cfu/100ml) & 0.00 & 100 & 37.8 & 10.00 & 7.07 \\
Alkalinity $(\mathrm{mg} / \mathrm{L})$ & 100.00 & 190 & 136 & 250.00 & 0.11 \\
\hline & & & & &
\end{tabular}

Table 2. Water Quality Classification based on Pollution Index (Caerio et al., 2005; Amadi et al., 2012)

\begin{tabular}{ccc}
\hline Class & Pollution Index (PI) & Status \\
\hline Class 1 & PI $<1$ & No Pollution \\
Class 2 & PI: $1-2$ & Slightly Polluted \\
Class 3 & PI: $2-3$ & Moderately Polluted \\
Class 4 & PI: $3-5$ & Strongly Polluted \\
Class 5 & PI: $>5$ & Seriously Polluted \\
\hline
\end{tabular}




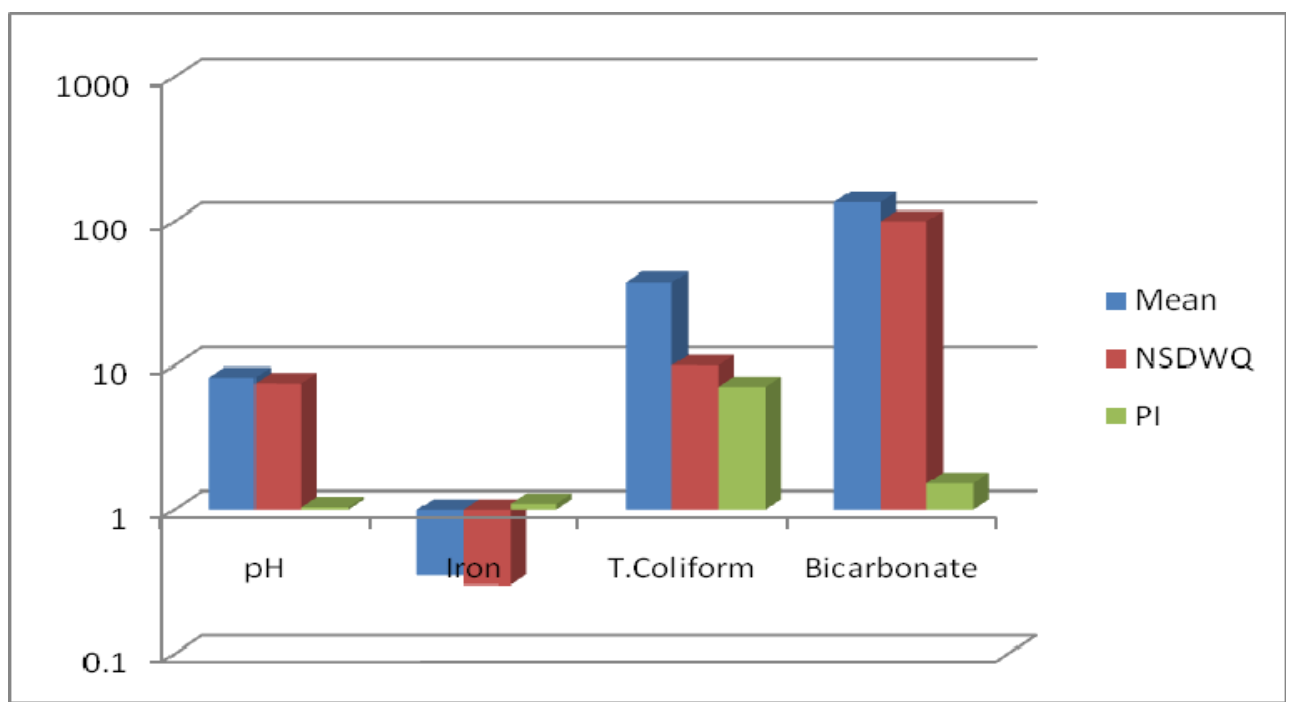

Figure 3. Bar chart showing the parameters whose mean concentration exceeds the recommended standard and the computed pollution index

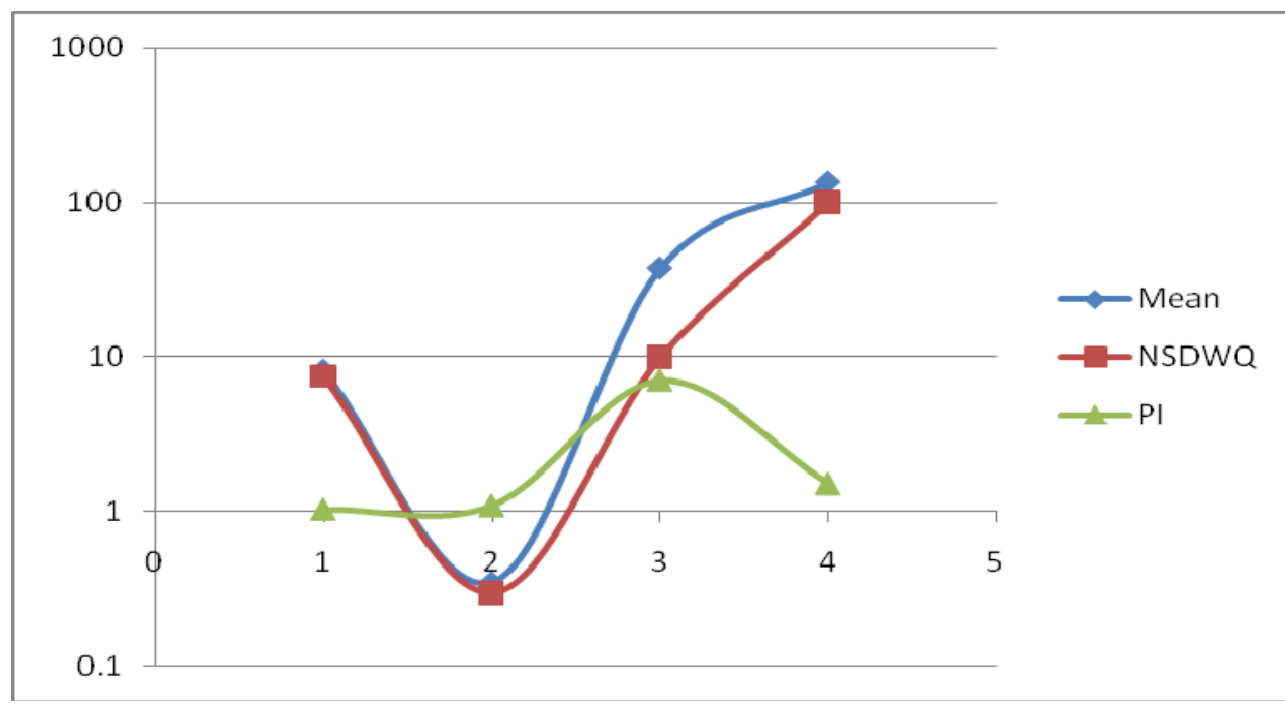

Figure 4. Graph of mean concentration of parameter analyzed, the recommended standard and the calculated pollution index

\section{Piper Diagram}

The concentration of eight major ions $\left(\mathrm{Na}^{+}, \mathrm{K}^{+}, \mathrm{Mg}^{2+}, \mathrm{Ca}^{2+}, \mathrm{Cl}^{-}, \mathrm{CO}_{3}{ }^{-}, \mathrm{HCO}_{3}{ }^{-}\right.$, and $\left.\mathrm{SO}_{4}{ }^{2-}\right)$ are represented on the Piper diagram by grouping the $\left(\mathrm{Na}^{+}\right.$with $\left.\mathrm{K}^{+}\right)$and the $\left(\mathrm{CO}_{3}^{-}\right.$with $\left.\mathrm{HCO}_{3}^{-}\right)$, thus reducing the number of parameters for plotting to six. On the Piper diagram, the relative concentration of the cations and anions are plotted in the lower triangles, and the resulting two points are extended into the central field to represent the total ion concentration (Figure 5). The Piper trilinear diagram is very useful in classifying the hydrochemical facies of the water samples according to their dominant ions. The water type in the area is mainly $\mathrm{Ca}-\mathrm{Mg} / \mathrm{CO}_{3}-\mathrm{HCO}_{3}$ type (Figure 5). 


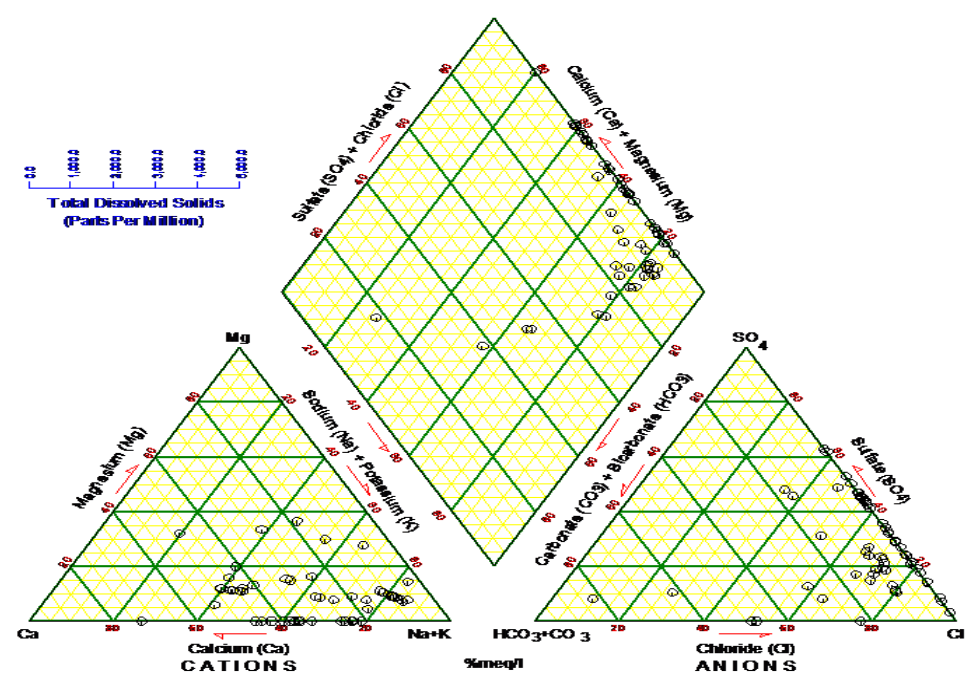

Figure 5. Piper diagram for groundwater from hand-dug wells in the area

\section{Conclusion}

Pollution index (PI) was employed in this study to assess the quality of groundwater from shallow aquifers in Erena and environs, Niger State, Nigeria. The application of pollution index on the geochemical data revealed that the groundwater from these shallow hand-dug well are seriously polluted with bacteria such E. coli and total coliform arising from human faeces and moderately/slightly polluted with iron, $\mathrm{pH}$ and bicarbonate, while the pollution status of remaining parameters were okay. It was observed that well samples collected far away from the pit-latrines/soakaway show no bacteriological contamination. This implies that the faecal contamination of the groundwater from the shallow aquifers can be attributed to the proximity of pit-latrines/soakaway to hand-dug wells. The dominant hydrochemical facies in the area is $\mathrm{Ca}-\mathrm{Mg} / \mathrm{CO}_{3}-\mathrm{HCO}_{3}$ type as shown in the Piper diagram. The efficiency of pollution index model in categorizing and interpreting the quality of groundwater in an area has been demonstrated in this study.

\section{Recommendations}

The following recommendations are made:

1) Future hand-dug wells and or boreholes should be located far away from dumpsite, pit-latrines and soakaway. The safe distance of $15 \mathrm{~m}$ should be maintained.

2) The use of existing hand-dug wells very close to unlined dumpsite, pit-latrines and soakaway should discontinue.

3) Standard VIP latrine and well-lined pit-latrines and soakaway should be enforced in the area.

4) Tapping of shallow aquifers for domestic purposes should stop due to their vulnerability to pollution. Subsequent boreholes/hand-dug wells should tap water from deeper aquifer that are less prone to contamination.

5) New hand-dug wells to be constructed should be lined with a concrete head above the ground level as illustrated in Plate 3. The lining mechanism impedes the movement of pollutant into the well thereby giving adequate protection to the well-water. 


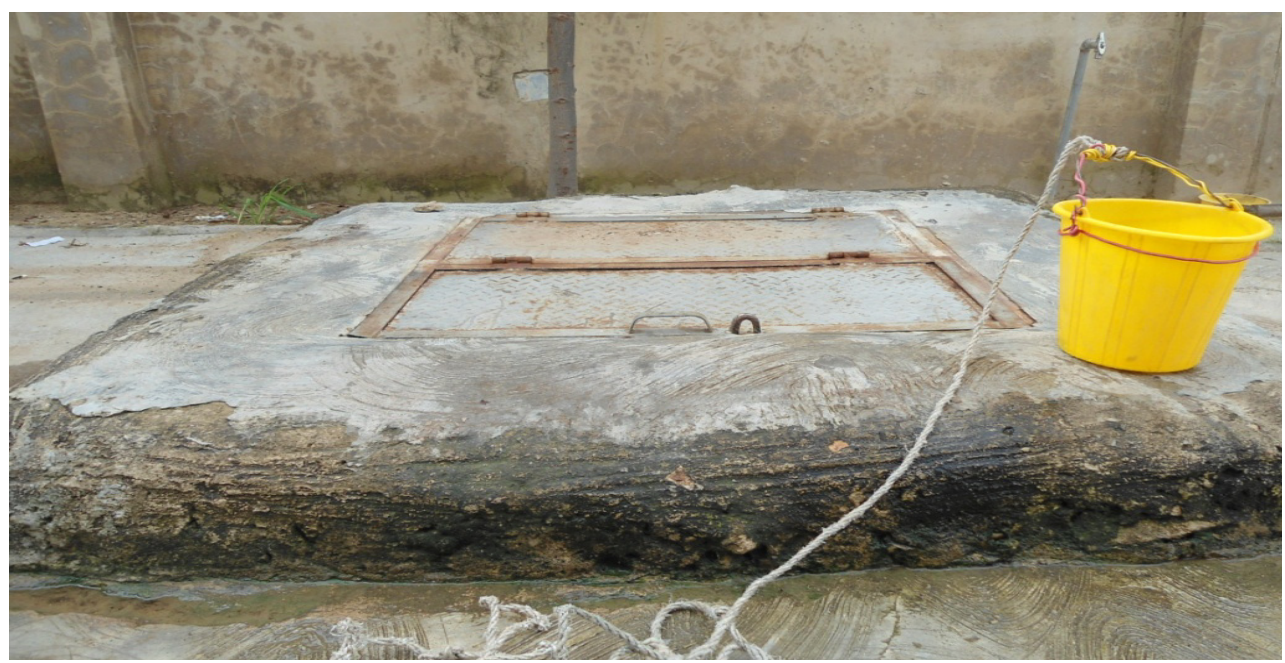

Plate 3. A typical lined hand-dug well recommended for the area

\section{References}

Ajibade, A. C., \& Wright, J. B. (1988). Structural Relationship in the Schist Belts of North Western Nigeria. In P. O. Oluyide (Eds). Precambrian geology of Nigeria. (pp. 103-109). A publication of Geological Survey.

Amadi, A. N. (2012). Quality Assessment of Aba River using heavy metal pollution index. American Journal of Environmental Enginerring, 2(1), 45-49.

Amadi, A. N., Olasehinde, P. I., Okosun, E. A., Okoye, N. O., Okunlola, I. A., Alkali, Y. B., \& Dan-Hassan, M. A. (2012a). Comparative study on the impact of Avu and Ihie dumpsites on soil quality in Southeastern Nigeria. American Journal of Chemistry, 2(1), 17- 23.

Amadi, A. N., Nwankwoala, H. O., Olasehinde, P. I., Okoye, N. O., Okunlola, I. A., \& Alkali, Y. B. (2012b). Investigation of aquifer quality in Bonny Island, Eastern Niger Delta, Nigeria using geophysical and geochemical techniques. Journal of Emerging Trends in Engineering and Apllied Sciences, 3(1), 180-184.

Amadi, A. N. (2011). Assessing the Effects of Aladimma dumpsite on soil and groundwater using water quality index and factor analysis. Australian Journal of Basic and Applied Sciences, 5(11), 763-770.

Amadi, A. N., Yisa, J., Okoye, N. O., \& Okunlola, I. A. (2010). Multivariate statistical evaluation of the hydrochemical facies in Aba, Southeastern Nigeria. International Journal of Biology and Physical Sciences, 15(3), 326-337.

APHA. (1998). Standard methods for examination of water and waste water. Publisher: APHA-AWWA-WPCF.

Caerio, S., Costa, M. H., Ramos, T. B., Fernandes, F., Silverira, N., Coimbra, A., ... Painho, M. (2005). Assessing heavy metal contamination in Sado Estuary sediment: An index analysis approach. Ecological Indicators, 5, 155-169.

Ezeigbo, H. I. (1989). Groundwater Quality Problems in parts of Imo State, Nigeria. Journal of Mining and Geology, 25(2), 1-9.

McCurry, P. (1983). The Geology of the Precambrian to Lower Paleozoic Rocks of Northern Nigeria. In C. A. Kogbe (Eds.). A review, in Geology of Nigeria. (pp. 15-39). Published by Elizabethan Co. Lagos.

NSDWQ. (2007). Nigerian Standard for Drinking Water Quality. Nigerian Industrial Standard, NIS, 554, 13-14.

Offodile, M. E. (1983). The occurrence and exploitation of groundwater in Nigeria basement rocks. Journal of Mining and Geology, 2, 131-146.

Olorunfemi, M. O., \& Fasuyi, S. A. (1993). Aquifer types, geoelectric and hydrogeologic characteristics of part of the Central Basement Terrain of Nigeria (Niger State). Journal of African Earth Sciences, 16, 309-317. http://dx.doi.org/10.1016/0899-5362(93)90051-Q

Olasehinde, P. I. (1999). An integrated geologic and geophysical exploration techniques for groundwater in the Basement Complex of West Central part part of Nigeria. Water Resources Journal, 10(1), 46-49.

Olasehinde, P. I., \& Amadi, A. N. (2009). Assessment of Groundwater Vulnerability in Owerri and its environs, 
Southeastern Nigeria. Nigeria Journal of Technological Research, 4(1), 27-40.

Olarewaju, V. O., Olorunfemi, M. O., \& Alade, O. (1996). Chemical characteristics of groundwater from some parts of the Basement Complex of central Nigeria. Journal of Mining and Geology, 33(2), 135-139.

Piper, A. M. (1944). A graphical procedure in the geochemical interpretation of water analysis. Trans. American Geophyscis Union, 25, 914-923. http://dx.doi.org/10.1029/TR025i006p00914

Prasad, B., \& Kumari, S. (2008). Heavy metal pollution index of ground water of an abandoned open cast mine filled of the water quality of River Adyar, India. Bulletin of Environmental Contamination and Toxicology, 82(2), 211-217.

Schroll, E. (1976). Analytische Geochemie Band II: Grundlagen and Anwendungen, Ferdinand Enke Verlag. Stuttgart, pp. 294-306.

World Health Organisation (WHO). (2006). International Standards for Drinking Water (3rd ed.). Geneva, pp. 346-385. 